\title{
Antibacterial Activity, Cytotoxicity, and the Mechanism of Action of Bacteriocin from Bacillus subtilis GAS101
}

\author{
Garima Sharma Shweta Dang Sanjay Gupta Reema Gabrani \\ Centre for Emerging Diseases, Department of Biotechnology, Jaypee Institute of Information Technology, \\ Noida, India
}

\section{Significance of the Study}

- This study reports the isolation and characterization of bacteriocin from Bacillus subtilis, an analysis of its cytotoxicity, and its mechanism of action. It showed the broad-spectrum antibacterial activity of bacteriocin produced by the soil isolate B. subtilis GAS101; the purified form not only inhibited the biofilm formation but also disrupted the preformed biofilm established by $S$. epidermidis. Hence, bacteriocin purified from B. subtilis GAS101 could be used to curtail bacterial biofilm and restrict infection.

\section{Keywords}

Cytotoxicity · Escherichia coli $\cdot$ In situ gel assay ·

Staphylococcus epidermidis · Scanning electron microscopy

\begin{abstract}
Objective: The aim of this study was to purify and characterize bacteriocin from the soil isolate Bacillus subtilis GAS101, and to determine its antimicrobial as well as antibiofilm potential. The purified bacteriocin was further analyzed and evaluated for mammalian cell cytotoxicity and the possible mode of action. Material and Methods: Bacteriocin from $B$. subtilis GAS101 (an animal husbandry soil isolate) was partially purified and checked for antimicrobial and antibiofilm activity against gram-positive and gram-negative bacteria. The molecular weight of bacteriocin was determined using tricine SDS-PAGE gel. The stability of bacteriocin was investigated at various temperatures and $\mathrm{pH}$ levels, and its sensitivity towards 8 enzymes and 6 chemicals was determined. Cytotoxicity analysis was performed on a Vero cell line by a
\end{abstract}

tetrazolium dye-based assay. Scanning electron microscopy (SEM) of bacteriocin-treated bacteria was carried out to determine the possible mode of action. Results: Bacteriocin from B. subtilis GAS101 was a potential inhibitor of both the indicator organisms (Staphylococcus epidermidis and Escherichia coli), and had a molecular weight of approximately 6.5 kDa. An in situ gel assay showed a zone of inhibition corresponding to the estimated protein band size. Bacteriocin was stable and showed antibacterial activity in broad ranges of temperature $\left(30-121^{\circ} \mathrm{C}\right)$ and $\mathrm{pH}(2-12)$. It was sensitive to 4 proteolytic enzymes, which indicated its proteinaceous nature. Bacteriocin showed $>70 \%$ cell viability on the mammalian Vero cell line. SEM depicted that the bacteriocin was able to disrupt the bacterial cell membrane as its probable mode of action. Conclusion: Thermostable and $\mathrm{pH}$-tolerant bacteriocin from $B$. subtilis GAS101, of about $6.5 \mathrm{kDa}$, showed broad-spectrum antimicrobial and antibiofilm activity.

C 2018 The Author(s)

Published by S. Karger AG, Basel

\begin{tabular}{|c|c|c|}
\hline KARGER & $\begin{array}{l}\text { (c) } 2018 \text { The Author(s) } \\
\text { Published by S. Karger AG, Basel }\end{array}$ & $\begin{array}{l}\text { Karger } \\
\text { Open access }\end{array}$ \\
\hline $\begin{array}{l}\text { ger@karger.co } \\
\text { er.com/mpp }\end{array}$ & $\begin{array}{l}\text { This is an Open Access article licensed } \\
\text { Attribution-NonCommercial- } 4.0 \text { Inte } \\
\text { (http://www.karger.com/Services/Ope } \\
\text { the online version of the article only. } L \\
\text { mercial purposes requires written per }\end{array}$ & $\begin{array}{l}\text { the Creative Commons } \\
\text { al License (CC BY-NC) } \\
\text { sLicense), applicable to } \\
\text { d distribution for com- }\end{array}$ \\
\hline
\end{tabular}

Reema Gabrani

Department of Biotechnology, Jaypee Institute of Information Technology A-10, Sector-62

Noida, 201309 UP (India)

E-Mail reema.gabrani@jiit.ac.in 


\section{Introduction}

Members of Bacillus spp. are known for their safe use in the food industry [1]. Some of the main representatives of the Bacillus group, like B. subtilis and B. licheniformis, have been designated as "generally recognized as safe" by the US FDA [2]. Bacillus is a gram-positive, aerobic, and endospore-forming bacterium with rod-shaped morphology, and it is widely distributed [3]. Due to endospore formation in adverse conditions, Bacillus bacteria can be found in soil and clays, rocks, dust, aquatic environments, vegetation, food, and the gastrointestinal tracts of various insects and animals [4].

Bacillus spp. have been reported to be a rich source of diverse bacteriocins, lipopeptides, and other bacteriocinlike inhibitory substances [1]. Bacteriocins are small, ribosomally synthesized antimicrobial peptides which are produced and secreted by bacteria for self-defense against the growth of closely related bacterial species [5]. Bacteriocins mainly restrict the growth of bacteria by pore formation on the cell surface or interference in cell wall synthesis [6].

B. subtilis has been shown to produce a wide range of bacteriocins, either class I or class II. Class I includes antibiotics that can undergo various posttranslational modifications whereas class II includes small, $\mathrm{pH}$ - and heatstable ribosomally synthesized peptides [1]. Subtilin, ericin S, and ericin A bacteriocins from Bacillus subgroups have been reported to only inhibit the growth of grampositive bacteria $[7,8]$.

According to the International Nosocomial Infection Control Consortium 2010, gram-positive (Staphylococcus spp.) and gram-negative (Escherichia coli) bacteria have been shown to acquire antibiotic resistance [9]. Gram-positive bacteria have been recognized as a common cause of hospital-acquired infection. Staphylococcus epidermidis has been recognized as the major causative agent responsible for nosocomial bacteremia. The development of resistance to drugs, allergic reactions, and side effects has led to the exploration of alternative drugs for the treatment of nosocomial infections [10]. Antimicrobial peptides are potent, broad-spectrum molecules which demonstrate potential as novel therapeutic agents. Bacteriocins isolated from bacteria are finding uses in the food industry but a plausible role as an alternative antimicrobial agent for infection is being explored [5].

Bacteriocins are generally safe, and stable, and have therapeutic potential as broad-spectrum antibiofilm agents. The objective of this study was to purify and characterize the bacteriocin produced by bacteriocinogenic
B. subtilis GAS101 and to determine its broad range of antimicrobial activity after evaluating its cytotoxic capability and mode of action.

\section{Materials and Methods}

Bacterial Strains and Growth Conditions

S. epidermidis and E. coli procured from the Microbial Type Culture Collection (Chandigarh, India), were used as indicator bacteria for the analysis of antimicrobial activities. The bacteria were cultured in nutrient broth at $37^{\circ} \mathrm{C}$ for $18-24 \mathrm{~h}$. B. subtilis GAS101 was grown overnight in deMan, Rogosa and Sharpe (MRS) broth at $30^{\circ} \mathrm{C}$ for $24 \mathrm{~h} \mathrm{[11].}$

\section{Purification of the Bacteriocin}

The B. subtilis cultured overnight was centrifuged at $10,000 \mathrm{~g}$ for $15 \mathrm{~min}$ at $4{ }^{\circ} \mathrm{C}$. Cell-free supernatant (CFS) containing bacteriocin-like inhibitory substances was sterilized by passing through a $0.45-\mu \mathrm{m}$ filter. Bacteriocin was precipitated using $70 \%$ ammonium sulfate at $4^{\circ} \mathrm{C}$, and the obtained pellet was dissolved in 20 mM PBS, pH 7.4. The salt was removed using a $3-\mathrm{kDa}$ ultramembrane filter, and the fraction containing the bacteriocin which did not pass through the filter (i.e., the retentate) was stored at $-20^{\circ} \mathrm{C}$. The minimum inhibitory concentration (MIC) showing $>95 \%$ bacterial growth inhibition was determined by a $96-$ well microtiter plate assay [12].

\section{Molecular Weight Determination and in situ Gel Activity}

The molecular mass of the bacteriocin was analyzed by running tricine SDS-PAGE [13]. The bacteriocin sample was applied in duplicate in the gel and separated using constant voltage $(90 \mathrm{~V})$. The first half of the gel was stained with Coomassie Blue R250, and the other half was placed on the nutrient agar plate and overlaid with soft agar containing S. epidermidis. The plate was analyzed for bacterial growth inhibition (at $37^{\circ} \mathrm{C}$ for $12 \mathrm{~h}$ ). The protein concentration of bacteriocin was determined by the Bradford method [14].

\section{Determination of Growth Curve}

The effect of bacteriocin on the growth of $S$. epidermidis and E. coli over a period of $24 \mathrm{~h}$ was studied by plotting the bacterial growth curve. Bacterial cell count of indicator organisms was adjusted equivalent to a final concentration of $1 \times 10^{6} \mathrm{CFU} / \mathrm{mL}$, followed by exposure to bacteriocin at $2 \times$ MIC, MIC, and $0.5 \times$ MIC values. Bacterial cultures were kept in a shaking incubator at $37^{\circ} \mathrm{C}$, and absorbance was measured at $595 \mathrm{~nm}$ at different time intervals (i.e., $0,2,4,8,10$, and $24 \mathrm{~h}$ ) to obtain growth curves for the bacteria [15].

\section{The Effects of Enzyme, pH, and Heat Treatment on}

Antimicrobial Activity

Purified CFS ( $\mathrm{pH}$ 6.0) was treated with 8 different enzymes (Table 1) to a final concentration of $1 \mathrm{mg} / \mathrm{mL}$ at $37^{\circ} \mathrm{C}$ for $2 \mathrm{~h}$. An enzyme was inactivated at $100^{\circ} \mathrm{C}$ for $10 \mathrm{~min}$, and the residual antimicrobial activity was examined by microtiter plate assay using $S$. epidermidis as an indicator organism. Buffer without an enzyme was used as a negative control. The effect of $\mathrm{pH}$ on the antimicrobial activity was determined by adjusting the bacteriocin to $\mathrm{pH}$ levels of $2,4,6,8,10$, and 12 with $1 \mathrm{~N} \mathrm{HCl} / 1 \mathrm{M} \mathrm{NaOH}$. After $2 \mathrm{~h}$ of 
incubation at $37^{\circ} \mathrm{C}$, the $\mathrm{pH}$ of the supernatant was readjusted to 6.0 , and the residual activity was determined by microtiter plate assay. Purified bacteriocin-containing samples were exposed to different temperatures, i.e., $30^{\circ}, 40^{\circ}, 50^{\circ}, 60^{\circ}, 70^{\circ}, 80^{\circ}$, and $100^{\circ} \mathrm{C}$ for $1 \mathrm{~h}$, and at $121^{\circ} \mathrm{C}$ for $15 \mathrm{~min}$. The residual activity of each sample was analyzed as described above. Bacteriocin was also treated with $10 \%$-concentrations of different chemicals/solvents (Table 1) and checked for remaining antimicrobial activity [16].

\section{Antibiofilm Analysis of Bacteriocin}

For the biofilm inhibition assay, a $1 \times 10^{6} \mathrm{CFU} / \mathrm{mL}$ sample of $S$. epidermidis was incubated with different concentrations of bacteriocin on a $96-$ well microtiter plate for $48 \mathrm{~h}$ at $37^{\circ} \mathrm{C}$. The adhered cells of biofilm were stained with crystal violet $(\mathrm{CV})$ dye as described by Sharma et al. [11], and the absorbance of the plate was measured at $595 \mathrm{~nm}$ in an ELISA reader (BioRad, CA, USA).

For the biofilm disruption assay, a biofilm of S. epidermidis was established on a 96 -well microtiter plate for $48 \mathrm{~h}$ at $37^{\circ} \mathrm{C}$. The plate was washed 3 times with PBS ( $\mathrm{pH} 7.4$ ) for the removal of nonadhered cells. The plate was incubated with varying concentrations of bacteriocin for $24 \mathrm{~h}$; CV staining was performed as before for the biofilm inhibition assay.

The $\%$ inhibition and disruption were calculated using the following formula:

$$
\% \text { inhibition }=\frac{\text { control } O D-\text { sample } O D}{\text { control } O D} \times 100 .
$$

Determination of Cytotoxicity on the Vero Cell Line

A Vero cell line obtained from an African green monkey kidney was maintained in DMEM with $10 \% \mathrm{FBS}$ at $37^{\circ} \mathrm{C}$ and $5 \% \mathrm{CO}_{2}$. The toxic effect of $B$. subtilis bacteriocin on the Vero cell line was determined by MTT assay. Vero cells were trypsinized and allowed to adhere to a 96 -well plate at $37^{\circ} \mathrm{C}$. Cells were then treated with different concentrations of bacteriocin (in triplicate) and the percentage viability was calculated as described by Sharma et al. [17].

\section{Scanning Electron Microscopy}

Bacterial surface changes after treating with bacteriocin at the MIC dose were visualized using scanning electron microscopy (SEM) [18]. The secondary culture of E. coli was incubated with the MIC of bacteriocin for $120 \mathrm{~min}$ at $37^{\circ} \mathrm{C}$. The E. coli cells were centrifuged at $6,000 \mathrm{~g}$ at $4^{\circ} \mathrm{C}$, and the obtained pellet was washed twice with $1 \mathrm{mM}$ of PBS ( $\mathrm{pH} 7$ ). Pellets were fixed with $8 \%$ glutaraldehyde overnight. The cells were washed with PBS, treated with a series of ethanol ( $5 \mathrm{~min}$ each), and critical point drying was done at $100 \%$ ethanol for $1 \mathrm{~h}$. SEM (JSM-7001F, JEOL, Tokyo, Japan) was used to visualize the morphological changes of bacterial cells treated with bacteriocin compared with nontreated cells.

\section{Results}

\section{Partial Purification of Bacteriocin}

The purified bacteriocin showed a molecular weight of approximately $6.5 \mathrm{kDa}$ on SDS-PAGE gel. The presence of a zone of inhibition on the bacterial agar plate corresponded to an approximately $6.5-\mathrm{kDa}$ gel band that indicated the location of active antimicrobial fraction (Fig. 1).
The in situ gel assay revealed that the antimicrobial activity was attributed to the $6.5-\mathrm{kDa}$ bacteriocin. The inhibition spectrum of partially purified bacteriocin showed antimicrobial activity on S. epidermidis with an MIC value of $1.44 \mathrm{mg} / \mathrm{mL}$. However, E. coli was sensitive at a higher concentration, i.e., $2.88 \mathrm{mg} / \mathrm{mL}$ of bacteriocin.

\section{Growth Curve Analysis}

Growth curves of E. coli and S. epidermidis indicated that the $2 \times$ MIC and MIC of bacteriocin inhibited the growth of E. coli and S. epidermidis completely, with a sharper fall in the OD of bacterial cells at the $2 \times \mathrm{MIC}$ (Fig. 2). The bacterial cells treated with the $0.5 \times$ MIC of bacteriocin showed reduced growth in comparison to the untreated cells.

\section{Sensitivity of Bacteriocin with Varying pH Levels,}

\section{Temperatures, and Enzymes}

The bacteriocin did not exhibit any antimicrobial activity against $S$. epidermidis after treatment with trypsin,

Table 1. Effect of temperature, $\mathrm{pH}$, enzymes, and organic solvents on the antimicrobial activity of partially purified bacteriocin from B. subtilis

Activity of bacteriocin

Temperature

$30^{\circ} \mathrm{C}, 40^{\circ} \mathrm{C}, 50^{\circ} \mathrm{C}, 60^{\circ} \mathrm{C}, 70^{\circ} \mathrm{C}, 80^{\circ} \mathrm{C}, \quad+$ and $100^{\circ} \mathrm{C}$ for $1 \mathrm{~h}$

$121^{\circ} \mathrm{C}$ for $20 \mathrm{~min}$

$\mathrm{pH}$ value

$2,4,6,8,10$, and $12+$

Enzyme (1 mg/mL)

Proteinase $\mathrm{K}$

Catalase

Pepsin

Papain

Trypsin

Amylase

Lysozyme

Lipase

\section{$+$}

Chemical (10\%)

EDTA

Urea

$\mathrm{NaCl}$

Benzene

Ethyl alcohol

DMSO

+, antimicrobial activity; -, no antimicrobial activity. 
pepsin, and proteinase $\mathrm{K}$, but it remained effective after treating with amylase and lipase. This indicates the proteinaceous nature of the bacteriocin (Table 1). The antimicrobial activity of bacteriocin on S. epidermidis did not change after exposure to varying $\mathrm{pH}$ levels (2-12) and temperatures $\left(20-121^{\circ} \mathrm{C}\right.$ ) (Table 1$)$. Bacteriocin activity was also unaffected by treatment with various chemicals.

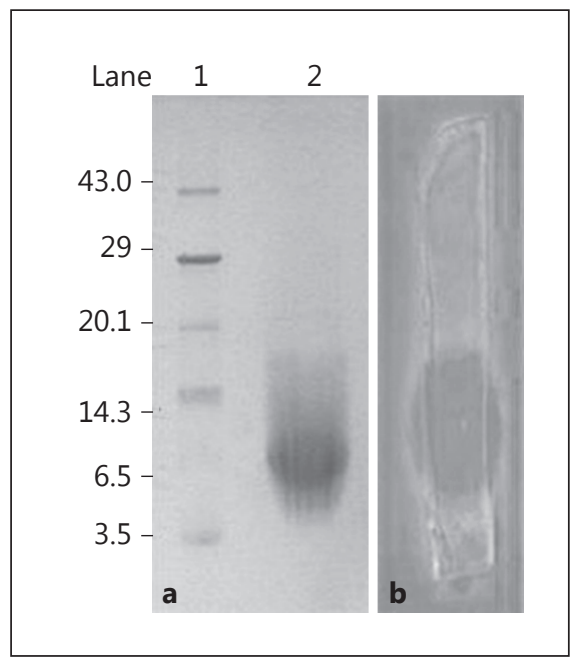

Fig. 1. Tricine SDS-PAGE of partially purified bacteriocin from $B$. subtilis GAS101 and the detection of the antibacterial activity in situ on a gel. a Lane 1: low range protein molecular weight markers; lane 2: bacteriocin precipitated by $70 \%$ ammonium sulfate. b Antibacterial activity of bacteriocin detected in situ on gel.

\section{Antibiofilm Activity}

At a concentration of $2.88 \mathrm{mg} / \mathrm{mL}$, bacteriocin showed $>85 \%$ inhibition and dispersal of the S. epidermidis biofilm. The inhibition of biofilm formation was more pronounced at half the above dose of bacteriocin, i.e., $1.44 \mathrm{mg} / \mathrm{mL}$, where the antibiofilm activity was found to be $85.24 \%$ and the eradication of the established biofilm was found to be $70.28 \%$ (Fig. 3). There was a drastic drop in the inhibition of biofilm at 0.72 $\mathrm{mg} / \mathrm{mL}$, to $<10 \%$. The purified bacteriocin showed dose-dependent antibiofilm activity against $S$. epidermidis biofilm formation as well as the dispersal of the established biofilm.

\section{Cytotoxicity of Bacteriocin on the Vero Cell Line}

Cytotoxicity analysis showed the viability of Vero cells to be $72 \%$ after treating with the MIC $(2.88 \mathrm{mg} / \mathrm{mL})$ of bacteriocin. The graphic representation of percentage viability with respect to dilution is shown in Figure 4. The results revealed that the viability of cells was dependent on the bacteriocin concentration.

\section{Scanning Electron Microscopy}

The images of $E$. coli cells treated with $2.88 \mathrm{mg} / \mathrm{mL}$ of bacteriocin showed a clear disruption of the membranes of the bacterial cells (Fig. 5). The SEM images showed that the pore formation could be one of the possible mechanisms for bactericidal action.

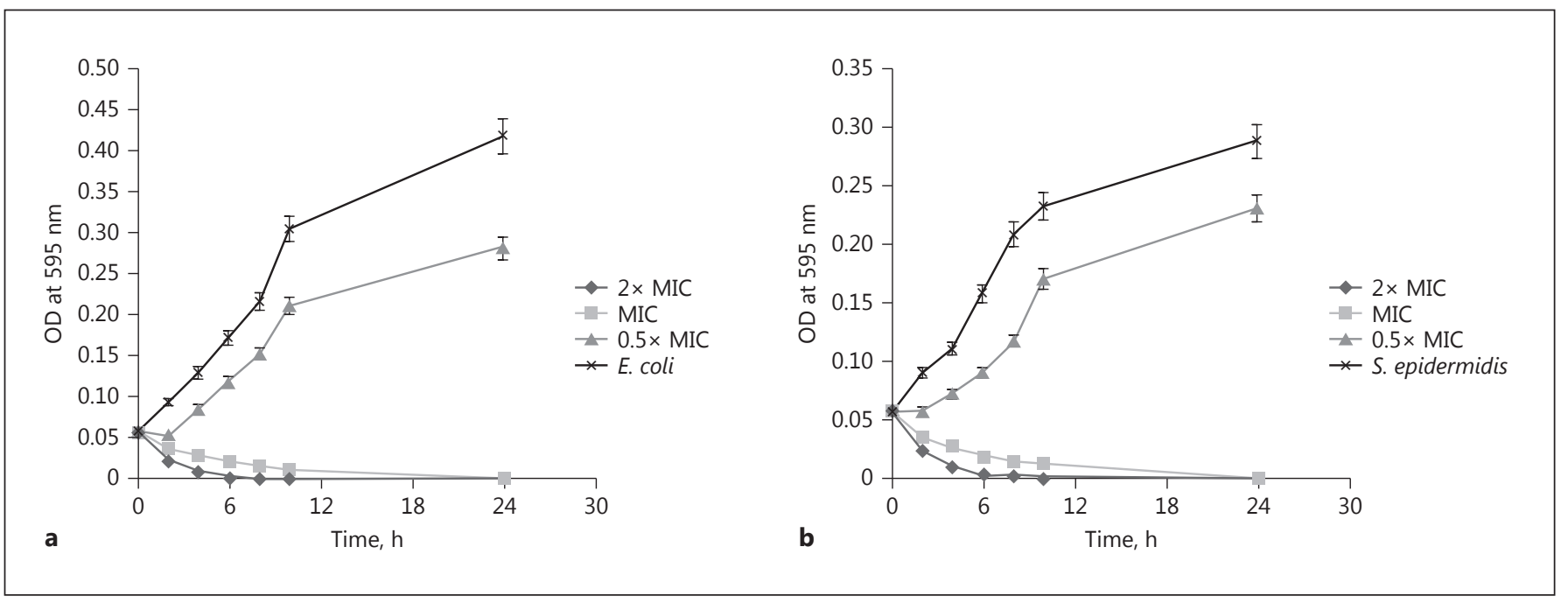

Fig. 2. Growth curve of E. coli (a) and S. epidermidis (b) after exposure to different concentrations of bacteriocin at $37^{\circ} \mathrm{C}$ over a period of $0-24 \mathrm{~h}$. 


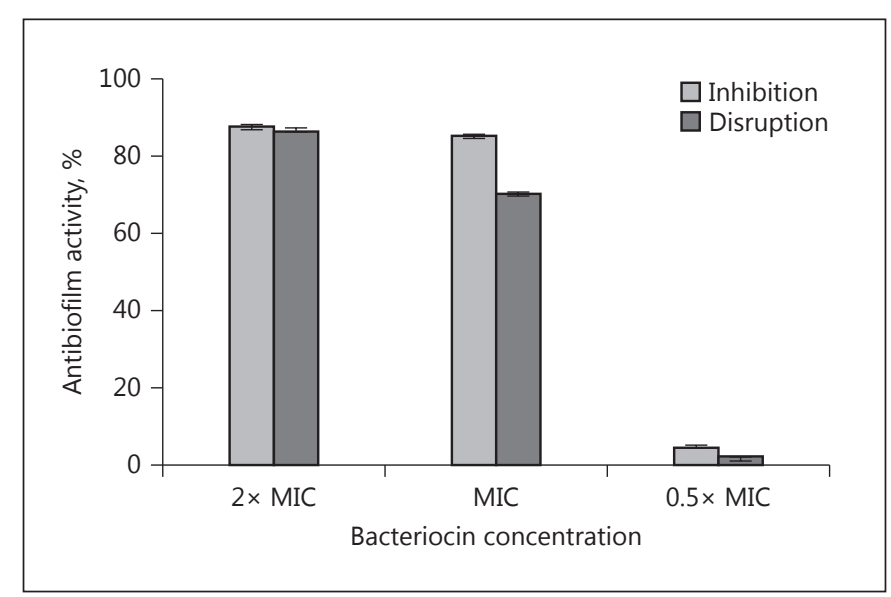

Fig. 3. Antibiofilm activity of bacteriocin on S. epidermidis biofilm formation as well as eradication of established biofilm at different concentrations detected by crystal violet staining assay.

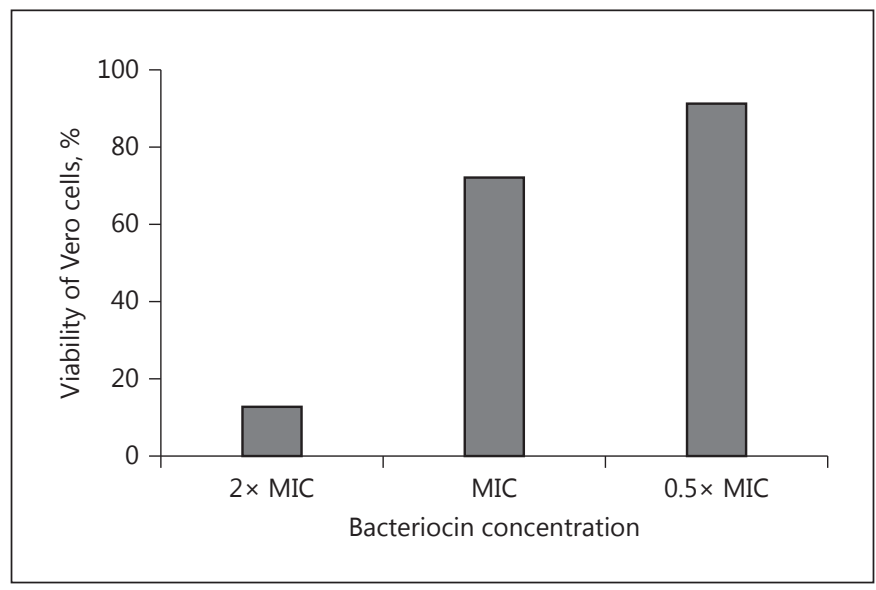

Fig. 4. Effect of different concentrations of bacteriocin on the viability of Vero cells. Cells were treated with $2 \times \mathrm{MIC}(5.76 \mathrm{mg} / \mathrm{mL})$, MIC $(2.88 \mathrm{mg} / \mathrm{mL})$, and $0.5 \times$ MIC $(1.44 \mathrm{mg} / \mathrm{mL})$ of bacteriocin for $24 \mathrm{~h}$ at $37^{\circ} \mathrm{C}$, and the percentage viability with respect to Vero cells was evaluated by MTT assay. Each bar represents mean \pm standard error.
Fig. 5. Morphological changes of sensitive bacterial cells incubated with a $2.88 \mathrm{mg} /$ $\mathrm{mL}$ concentration of bacteriocin as observed by scanning electron microscopy. a Untreated E. coli was used as a control. b Morphological changes on the surface of E. coli treated with bacteriocin. Arrows point towards pores formed by bacteriocin.
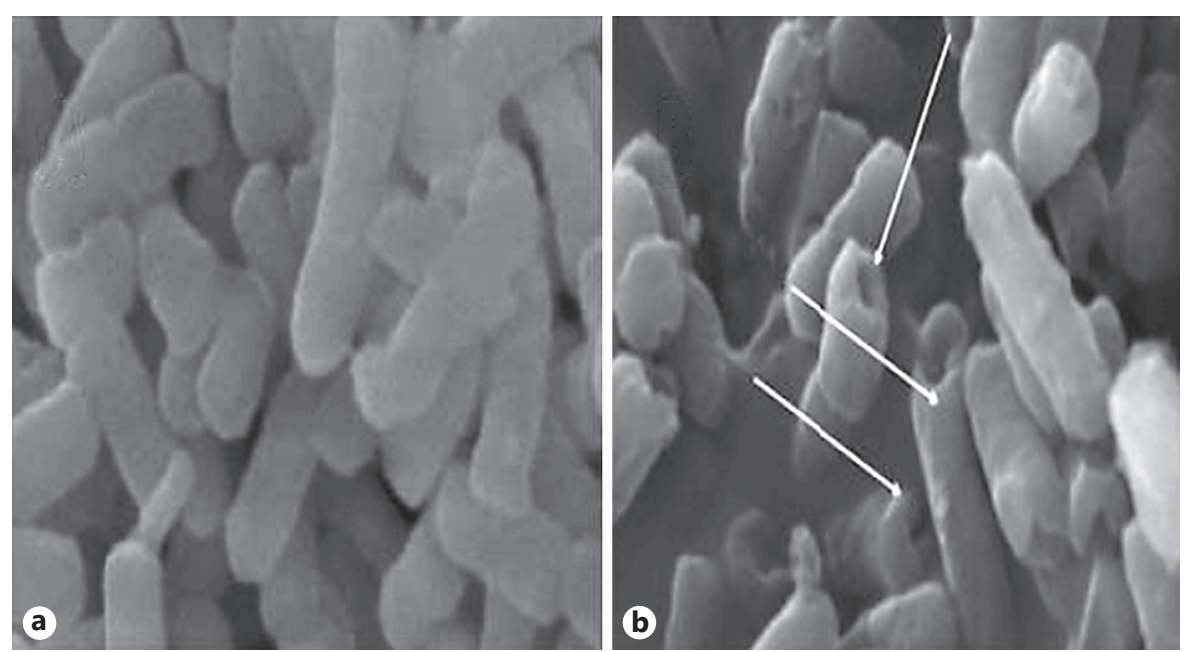

\section{Discussion}

In this study, the bacteriocin purified by ammonium sulfate precipitation exhibited in situ gel activity that corresponded to the $6.5-\mathrm{kDa}$ band, similar to the 6.3 - and $6.5-\mathrm{kDa}$ bacteriocin activity reported previously by Xie et al. [19] and Huang et al. [20], respectively. Our findings and theirs appear to corroborate the recent report that communication and competition between bacterial communities in diverse set-ups have contributed significantly towards the real diversity and complexity of bacteriocins across genera [21].
The bacteriocin used in this study was purified from an animal farm soil isolate, B. subtilis GAS101 [11]. Animal husbandry soil being enriched with straw, cow dung, urine, and raw milk, can contribute to the growth of diverse bacteria. Thus, B. subtilis GAS101, isolated from this relatively unexplored area for bacteriocinogenic bacterial species, could be the source of a distinct bacteriocin.

There are quite a few reports in which bacteriocins have been characterized from different sources and have been found to elicit antimicrobial activity against different bacterial species [22]. Hence, Bacillus subgroups have been reported to produce a diverse range of bacte- 
riocins with different molecular weights, like subtilin, ericin $\mathrm{A}$, ericin $\mathrm{S}$, coagulin, cerein $7 \mathrm{~A}$, and cerein $7 \mathrm{~B}$ [1]. The bacteriocins from Bacillus spp. have been mainly shown to be active against food-borne pathogens, and there are very few reports on the biomedical applications. This emphasizes the need to study and characterize bacteriocin from different sources with variations of size, physicochemical properties, and inhibitory spectrum.

The purified bacteriocin in our study exhibited a broad range of antimicrobial activity against both gram-positive S. epidermidis and gram-negative E. coli, at 1.44 and 2.88 $\mathrm{mg} / \mathrm{mL}$, respectively. In many studies, it has been shown that the further purification steps help in lowering the MIC, implying that this could help in the reduction of MIC dose against specific microorganisms. Various studies have indicated variable effective ranges of bacteriocin for bacterial growth inhibition, depending on the source, the type of bacteriocin, and the target organism. Shelburne et al. [23] reported that subtilosin A (3,399.7 Da) from B. subtilis displayed an MIC of $>200 \mathrm{mg} / \mathrm{L}$ against S. epidermidis ATCC 12228 and $>100 \mathrm{mg} / \mathrm{L}$ against E. coli. In another study, partially purified bacteriocin from soil isolate B. subtilis RLID 12.1 inhibited the growth of S. epidermidis at $>200 \mu \mathrm{g} / \mathrm{mL}$ and did not exhibit any activity against E. coli [24]. The bacteriocin in our study displayed antimicrobial activity against a broad spectrum of grampositive and gram-negative bacteria. The variation in antimicrobial activity has been attributed to the selective pressure and the genetic profile of different bacterial strains. It has been proposed that the outer membrane of gram-negative bacteria safeguards its inner membrane, and so higher doses of bacteriocin are required for inhibition of its growth [25]; this is in agreement with our finding.

The bacteriocin purified from B. subtilis GAS101 showed sensitivity towards protein-degrading enzymes, which demonstrates its proteinaceous nature. The bacteriocin activity did not alter after treatment with lipase, lysozyme, and amylase, which confirms that lipid and carbohydrate moieties are not required for its biological action. The purified bacteriocin showed stability across wide ranges of temperature and $\mathrm{pH}$. Many of the bacteriocins obtained from Bacillus spp. have been reported to be proteins or peptides [1]. The stability at broad $\mathrm{pH}$ and temperature ranges has been attributed to the unusual amino acids in antimicrobial substances which provide strength to tolerate variations [26]. The activity of bacteriocin in our study remained unaffected after treatment with different chemicals, indicating no change in activity under different storage conditions [26]. The stability data indicate that the bacteriocin from B. subtilis GAS101 belongs to the antibiotic class of the bacteriocin classification.

The antibiofilm potential of partially purified bacteriocin on the inhibition of biofilm formation as well as the effect on the established biofilm was analyzed on S. epidermidis, an opportunistic dermal pathogen known mainly for biofilm formation on wounds and medical devices [27]. Partially purified bacteriocin from $B$. subtilis GAS101 eradicated the established biofilm at double the dose required to inhibit biofilm formation. This confirms the observation of the biofilm formation tendency of $S$. epidermidis to make the eradication more complicated than the inhibition [28]. There are a few reports of bacteriocin activity against biofilm; $B$. sonorensis has been reported to produce a bacteriocin, sonorensin, with $50 \%$ activity against the biofilm of S. aureus [2]. Thus, biofilms are more resistant than planktonic cells towards treatment, as we observed in this study where bacteriocin at $1.44 \mathrm{mg} / \mathrm{mL}$ exhibited $85.24 \%$ antibiofilm activity versus the $>95 \%$ against the planktonic culture of $S$. epidermidis.

The cytotoxic study of purified bacteriocin conducted on the Vero cell line showed $>70 \%$ viability at the MIC with respect to the untreated cells. The crude antimicrobial substance (4\%) of B. subtilis showed $6 \%$ cytotoxicity on Caco-2 cells, and in another study, bacteriocin from Bacillus sp. DUA4 showed 48 and $91 \%$ cell viability on HEK293 and HT29 cells, respectively [29]. Bacteriocins have been reported for their variable effect (nil to cytotoxic) on this mammalian cell line, and this is due to different preparation, varying duration of exposure, and many other factors. Cell surface hydrophobicity can affect the binding of the peptide, which can lead to variations in the cytotoxicity, but the actual mechanism involved in the difference in toxicity is still not completely elucidated [30].

The mode of action of purified bacteriocin from $B$. subtilis GAS101 showed the presence of perturbations and pores on the bacterial cell membrane, indicating the squeezing out of the inner material which could be the possible mode of action. Pore formation on the bacterial cell membrane has been reported to be one of the known mechanisms for bactericidal action of the bacteriocin. Transmission electron microscopy of Listeria monocytogenes cells treated with cerein $8 \mathrm{~A}$, a bacteriocin from $B$. cereus, showed damaged cell walls (indicating membrane disruption) [8]. 


\section{Conclusion}

In this study, the partially purified bacteriocin from the CFS of B. subtilis GAS101 had a molecular weight of approximately $6.5 \mathrm{kDa}$. The bacteriocin elicited the inhibitory zone at the same location by in situ gel assay. It showed inhibitory activity against both gram-positive and gram-negative indicator strains. Thermostable and $\mathrm{pH}$-tolerant proteinaceous bacteriocin impaired bacterial biofilm formation and disrupted the biofilm established by S. epidermidis. The MTT assay revealed a $72.20 \%$ viability of Vero cells after treating with bacteriocin. The SEM revealed that bacteriocin targets the bacterial cells as one of its mechanisms of antibacterial activity.

\section{Acknowledgements}

We thank the Department of Biotechnology, Jaypee Institute of Information Technology, Noida, UP, India, for providing the infrastructural facility to carry out the research work.

\section{Disclosure Statement}

There were no conflicts of interest.

\section{References}

1 Abriouel H, Franz CM, Omar NB, et al: Diversity and applications of Bacillus bacteriocins. FEMS Microbiol Rev 2011;35:201-232.

2 Chopra L, Singh G, Jena K, et al: Sonorensin: a new bacteriocin with potential of an antibiofilm agent and a food bio preservative. Sci Rep 2015;5:13412.

3 O'Sullivan L, Ross RP, Hill C: Potential of bacteriocin-producing lactic acid bacteria for improvements in food safety and quality. Biochimie 2002:84:593-604.

4 Nicholson WL: Roles of Bacillus endospores in the environment. Cell Mol Life Sci 2002;59: 410-416.

5 Cotter PD, Ross RP, Hill C: Bacteriocins - a viable alternative to antibiotics? Nature Rev Microbiol 2013;11:95-105.

6 Bierbaum G, Sahl HG: Lantibiotics: mode of action, biosynthesis and bioengineering. Curr Pharm Biotechnol 2009;10:2-18.

7 Teixeira ML, Dalla Rosa A, Brandelli A: Characterization of an antimicrobial peptide produced by Bacillus subtilis subsp. spizezinii showing inhibitory activity towards Haemophilus parasuis. Microbiol 2013;159:980-988.

8 Bizani D, Motta AS, Morrissy JA, et al: Antibacterial activity of cerein $8 \mathrm{~A}$, a bacteriocinlike peptide produced by Bacillus cereus. Int Microbiol 2010;8:125-131.

9 Hashemizadeh Z, Bazargani A, Davarpanah MA: Blood culture contamination in a neonatal intensive care unit in Shiraz, Southwest Central Iran. Med Princ Pract 2011;20:133-136.

10 Agarwal S, Sharma G, Dang S, et al: Antimicrobial peptides as anti-infectives against Staphylococcus epidermidis. Med Princ Pract 2016;25:301-308

11 Sharma G, Dang S, Gupta S, et al: Identification and molecular characterization of bacteria having antimicrobial and antibiofilm activity. Int J Pharm Pharm Sci 2016;8:111-114
12 Balouiri M, Sadiki M, Ibnsouda SK: Methods for in vitro evaluating antimicrobial activity: a review. J Pharma Analysis 2016;6:71-79.

13 Schägger H, Von Jagow G: Tricine-sodium dodecyl sulfate-polyacrylamide gel electrophoresis for the separation of proteins in the range from 1 to $100 \mathrm{kDa}$. Analyt Biochem 1987;166:368-379.

14 Bradford MM: A rapid and sensitive method for the quantitation of microgram quantities of protein utilizing the principle of proteindye binding. Analyt Biochem 1976;72:248254.

15 Kim SH, Lee HS, Ryu DS, et al: Antibacterial activity of silver-nanoparticles against Staphylococcus aureus and Escherichia coli. Korean J Microbiol Biotechnol 2011;39:77-85.

16 Batdorj B, Dalgalarrondo M, Choiset Y, et al: Purification and characterization of two bacteriocins produced by lactic acid bacteria isolated from Mongolian airag. J Appl Microbiol 2006; 101:837-848

17 Sharma G, Raturi K, Dang S, et al: Inhibitory effect of cinnamaldehyde alone and in combination with thymol, eugenol and thymoquinone against Staphylococcus epidermidis. J Herb Med 2017;9:68-73.

18 Barbour A, Philip K, Muniandy S: Enhanced production, purification, characterization and mechanism of action of salivaricin 9 lantibiotic produced by Streptococcus salivarius NU10. PLoS One 2013;8:e77751.

19 Xie J, Zhang R, Shang C, et al: Isolation and characterization of a bacteriocin produced by an isolated Bacillus subtilis LFB112 that exhibits antimicrobial activity against domestic animal pathogens. Afr J Biotechnol 2013;8:20.

20 Huang T, Zhang X, Pan J, et al: Purification and characterization of a novel cold shock protein-like bacteriocin synthesized by Bacillus thuringiensis. Sci Rep 2016;6:35560.
21 Collins FWJ, O'Connor PM, O'Sullivan O, et al: Bacteriocin gene-trait matching across the complete Lactobacillus pan-genome. Sci Rep 2017;7:3481.

22 Kaškonienė V, Stankevičius M, BimbiraitèSurviliene K, et al: Current state of purification, isolation and analysis of bacteriocins produced by lactic acid bacteria. Appl Microbiol Biotechnol 2017;101:1323-1335.

23 Shelburne CE, An FY, Dholpe V, et al: The spectrum of antimicrobial activity of the bacteriocin subtilosin A. J Antimicrob Chemother 2007;59:297-300.

24 Ramachandran R, Chalasani AG, Lal R, et al: A broad-spectrum antimicrobial activity of Bacillus subtilis RLID 12.1. ScientificWorldJournal 2014;2014:968487.

25 Prudêncio C, Vieira M, Teresinha DS, et al: Strategies for the use of bacteriocins in gramnegative bacteria: relevance in food microbiology. J Food Sci Technol 2015;52:5408-5417.

26 Bhonsle JB, Clark T, Bartolotti L, et al: A brief overview of antimicrobial peptides containing unnatural amino acids and ligand-based approaches for peptide ligands. Curr Top Med Chem 2013;13:3205-3224.

27 Büttner H, Mack D, Rohde H: Structural basis of Staphylococcus epidermidis biofilm formation: mechanisms and molecular interactions. Front Cell Infect Microbiol 2015;5.

28 Otto M: Staphylococcus epidermidis - the "accidental" pathogen. Nat Rev Microbiol 2009; 8:555.

29 Poormontaseri M, Hosseinzadeh S, Shekarforoush SS, et al: The effects of probiotic Bacillus subtilis on the cytotoxicity of Clostridium perfringens type A in Caco-2 cell culture. BMC Microbiol 2017;17:150.

30 Laverty G, Gilmore B: Cationic antimicrobial peptide cytotoxicity, SOJ Microbiol Infect Dis 2014;2:1-8. 